\title{
MAXIMS OF POLITENESS IN STUDENTS-LECTURERS WHATSAPP CONVERSATIONS
}

\author{
Widya* \\ English Education Department, Indraprasta PGRI University \\ Received on 11 July 2017 / Approved on 5 September 2017
}

\begin{abstract}
This present study aims at analyzing the application and the violation of maxims of politeness in students' language in communicating with lecturers via WhatsApp and at identifying which utterances are considered polite and which ones are not based on the five pragmatic scales. In the descriptive-qualitative research, the writer applies Leech's theory of politeness principle in finding the answers to those questions. The results show that the language used by students in communicating with the lecturer through WhatsApp is considered polite where the amount of politeness maxims application is much higher when compared to the violation of those maxims. Violations are only found at tac and approbation maxim. The absence of violations of generosity, modesty, agreement, and sympathy maxim is due to the authority of the hearer and the social distance between speakers and hearers. The context of speech is also very helpful for students to speak politely, i.e. most of the contexts indicate that the students contact the lecturers because there is a need or interest they should discuss with the lecturer related to their academic maters. The politeness of students' utterance in the data can be measured with the five pragmatics scales.
\end{abstract}

Keywords: politeness, maxim of politeness, self and other, pragmatic scales

\begin{abstract}
ABSTRAK
Penelitian ini bertujuan untuk menganalisa penerapan dan pelanggaran maksim kesopanan pada bahasa yang digunakan mahasiswa dalam berkomunikasi dengan dosen melalui WhatsApp. Selain itu, penelitian ini juga bertujuan untuk mengidentifikasi ujaran apa saja yang dianggap sopan ataupun tidak sopan berdasarkan lima skala pragmatik. Dalam penelitian deskriptif-kualitatif ini, penulis menggunakan teori prinsip kesantunan dari Leech untuk memperoleh jawaban atas pertanyaan-pertanyaan penelitian di atas. Hasil yang diperoleh menunjukkan bahwa bahasa yang digunakan mahasiswa dalam berkomunikasi dengan dosen melalui WhatsApp dapat dianggap sopan. Hal ini bisa dilihat dari jumlah penerapan maksim kesopanan yang lebih tinggi dibandingkan pelanggarannya. Pelanggaran terhadap maksim kesopanan hanya ditemukan pada maksim kebijaksanaan (tact maxim) dan maksim penghargaan (approbation maxim). Tidak adanya pelanggaran terhadap maksim kedermawanan (generosity maxim), maksim kesederhanaan (modesty maxim), maksim mufakat (agreement maxim), dan maksim simpatisan (sympathy maxim) dikarenakan otoritas pendengar dan jarak sosial antara pembicara dan pendengar. Konteks percakapan juga membantu mahasiswa untuk bertutur kata dengan sopan, dimana kebanyakan konteks mengindikasikan bahwa mahasiswa menghubungi dosen karena mereka perlu atau berniat berdiskusi dengan dosen mengenai hal-hal yang bersifat akademik.

Kata Kunci: kesopanan, maksim kesopanan, diri sendiri dan orang lain, skala pragmatik
\end{abstract}

\section{INTRODUCTION}

I was very interested when a friend told me about the language used by her students when communicating through WhatsApp social media. She said that the language used by the students was very casual and it seemed that they have a very close relationship with her. In other words, the language used indicates that the students consider her a best friend. This nonstandard language does not only used when students

\footnotetext{
*Author(s) Correspondence:

E-mail: widya.center@gmail.com
} 
talk about their personal issues with my friend, but also when they talk about academic matters. I then compared my friend's story with my personal experience when talking with students through WhatsApp. I think I have not found anything like what my friend experienced above. I see that the messages I received from students are messages that use standard, polite language and indicate differences in status between students and lecturers.

What is the standard of politeness that students hold when communicating with their lecturers? Why do they choose a kind of language from another one if they communicate with certain lecturers? What kind of politeness strategy they use when communicating with lecturers through WhatsApp? Then what rules govern the actions, the use of language, and the interpretation of the actions' and utterances' meaning? These questions are very interesting to answer because they are related to our daily communication activities and perhaps we have not realized that linguists have formulated various theories to answer those questions.

Politeness has been a discussion of expert since decades before. Gunarwan (2007) mentions two experts whose works are widely referred in discussing politeness. They are Brown and Levinson (1987) and Leech (1983). Brown and Levinson (1987) revealed that every person has a concept of face, and everyone also realizes that the face is owned by others. This concept applies universally. Everyone always keeps and works together to respect each other's faces although in everyday practice there are people who take actions threatening, destroying, or reducing respect for one's face. The face, according to Brown and Levinson (1987) is divided into two; positive face and negative face. The negative face is one's desire that his actions are not blocked by others; while the positive face is one's desire to be acceptable to others. For a speech that threatens the listener's positive face, the speaker will use a positive politeness strategy, and vice versa, for a speech that threatens the negative face of the listener, the speaker will use a negative politeness strategy.

Previously, Leech (1983) in the previous study revealed that a communicative interaction requires another principle besides the principle of cooperative principle, namely politeness principle. This principle of politeness relates to two participants of the conversation, i.e. self and other. Self is the speaker, and the other person is the hearer and the third person who is being told or discussed by the speaker and the hearer (Wijana, 1996). Politeness principle is expressed in six maxims. Maxim is a linguistic rule in lingual interaction, the rules governing actions, the use of language, and interpretations of the actions and utterances. In addition, the maxim is also referred to as a pragmatic form based on the cooperative principle and the politeness principle. These maxims suggest that we express our beliefs politely and avoid impolite speech. Of these principles, there are four maxims involving two-pole scales, namely cost-benefit and praise-dispraise. These four maxims are the tact maxim, the generosity maxim, the approbation maxim, and the modesty maxim. The other two maxims (the agreement maxim and the sympathy maxim) involve scales of only one pole, the scale of agreement and the scale of sympathy. Although between one scale and another are related, each maxim is distinctly different, since each maxim refers to different rating scale. The maxims od Politeness principle tend to go in pairs as (I) Tact maxim (in impositives and commissives): (a) minimize cost to other; [(b) maximize benefit to other]; (II) Generosity maxim (in impositives and commissives): (a) minimize benefit to self; [(b) maximize cost to self]; (III) Approbation maxim (in expressives and assertives): (a) minimize dispraise of other; [(b) maximize praise of other]; (IV) Modesty maxim (in expressives and assertives): (a)

\footnotetext{
*Author(s) Correspondence:

E-mail: widya.center@gmail.com
} 
minimize praise of self; [(b) maximize dispraise of self]; (V) Agreement maxim (in assertives): (a) minimize disagreement between self and other; [(b) maximize agreement between self and other]; (VI) Sympathy maxim (in assertives): (a) minimize antipathy between self and other; [(b) maximize sympathy between self and other] (Leech, 1983, p. 132).

Leech (1983) reveals that there are several scales that can be used to determine whether an utterance. can be judged as polite or not. 1) Cost-benefit scale on which is estimated the cost and benefit of the proposed action A to speaker or hearer. It refers to the magnitude of the cost and benefit caused by an act of speech in an utterance. The more the speech is detrimental to the speaker, the more polite it is and vice versa. 2) The optionality scale on which illocution are ordered according to the amount of choice which speaker allows to hearer. This scale refers to many or little the options that speaker gives to hearer in an utterance. The more the utterance allows hearer to make a lot of choice, the more polite the utterance will be, and vice versa. 3) Indirectness scale on which, from the speaker's point of view, illocutions are ordered with respect to the length of the path (in terms of means-ends analysis) connecting the illocutionary act to its illocutionary goal. This scale refers to the direct or indirect rating of the meaning of a speech. The more direct the utterance, the more impolite it will be and vice versa. (4) Authority scale which measures the degree of distance in terms of the power or authority of one participant over another. Someone in authority may use familiar form of address to someone who, in return, uses the respectful form. (5) Social distance scale which refers to the scale of social relationship between speaker and hearer. There is a tendency where the closer the relationship is the less polite the utterance will be and vice versa.
The studies about politeness principle and its maxims are numerous. One of the has been done by Nadar, quoted from his book "Pragmatik dan Penelitian Pragmatik (2009). $\mathrm{He}$ analyzed political language used by Indonesian Politicians during the time of general election in 2004. The study was aimed at explaining the polite and impolite language of Indonesian politicians and also at providing a limited corpus of polite and impolite utterances of Indonesian politicians. The results showed that polite utterance obeyed the maxims of politeness and the impolite ones violated the maxims. The most frequently used maxim is sympathy maxim. Furthermore, the violation of maxims happened due to the external influences which threatened the politicians' self-esteem and their authority.

This present research aims at analyzing the application of politeness principle in students' language in communicating with lecturers via WhatsApp. Furthermore, the writer wants to identify which maxims of politeness principle are obeyed or violated by students when communicate with lectures via WhatsApp, which utterances are considered polite and which ones are not based on the five pragmatics scales proposed by Leech (1983).

\section{RESEARCH METHOD}

The method used in this study is descriptive-qualitative method. The data is in the form of written messages sent by students to their lectures talking about academic matters. Although the data are in the form of written messages, the writer will use the terminology "utterance" referring to the written messages, speaker referring to the senders of the messages and hearers referring to the receivers of the messages. There are some steps done in conducting this research. Firstly, (1) identifying utterance related to the obedience and the violation of politeness maxims. (2) Codifying the data by using

\footnotetext{
*Author(s) Correspondence:

E-mail: widya.center@gmail.com
} 
symbol as I/W/08 where 01 refers to the type of maxim, tac maxim is codified as (I), generosity maxim is (II), approbation maxim (III), modesty maxim is (IV), agreement maxim (V), and sympathy maxim is (VI), W refers to the initial letter of the lecturer's name, and 08 refers to the number of message received by the lectures. (3) Analyzing the obedience and violation of the politeness maxims. (4) Classifying the politeness maxims obeyed or violated and also identifying the pragmatics scale of the utterance. Finally, (5) drawing the conclusion.

\section{RESULTS AND DISCUSSION}

The results of data analysis show the application and violation of maxims of principle. Each obedience and violation are marked with certain words, phrases, or sentences that result in a speech may be said to meet or violate the maxim of politeness. In addition to linguistic features, the context of speech greatly affects the interpretation. The following analysis and discussion will show some examples of the obedience and the violation of politeness maxims when a student communicates with his lecturer through WhatsApp.

\section{Application and Violation of the Tact Maxim}

The tact maxim applies to the impositives and commisives.. At this maxim, the participants are supposed to keep the principle to always minimize cost to other and maximize benefit to other in communicating. The person who holds and performs the tact maxim can be regarded as a polite person. Feelings of hurt as a result of the treatment that less beneficial to other can be minimized if the tact maxim is held firmly and carried out in communicating. Here are examples of conversations of students and lecturers that meet the tact maxims.

Datum I/I/01
R : Assalamualaikum ma'am I. Saya hanya mau mengingatkan kembali untuk Grammar Class yang nanti dibina/diajarkan oleh ma'am I, akan dilaksanakan pada jam $13.30 \mathrm{~s} / \mathrm{d}$ 15.10, di ruang kelas 406/4 ya Ma'am. Dan untuk materi yang nanti akan diberikan, itu Ma'am saja yang menentukan karna Grammar Class ini dibuka untuk semua fakultas di UNAS ma'am. Sebelumnya terima kasih banyak ma'am karna sudah bersedia untuk menjadi pengajar di kelas Grammar.

I : Waalaikumsalam. Okay Rima. Saya ada kelas jam 9-1. Saya ingat kok.

The context of the above conversation is a student ( $\mathrm{R}$ ) who is a Students Association board is contacting a lecturer (I) to remind the lecturer about Grammar Class activities that have been approved by the lecturer. In the above-mentioned situation $\mathrm{R}$ meets the tac maxim by minimizing cost of other and maximizing the profit of other by using sentence "Ma'am saja yang menentukan karna Grammar Class ini dibuka untuk seтиa fakultas di UNAS Ma'am". The politeness of this utterance can be measured with costbenefit scale and the optionality scale. By using cost-benefit scale the utterance can be considered polite because the benefit is on the hearer's side. Optionality scale which refers to the amount of options given by speaker to the hearer. The more speaker allows hearer to make the choice the more polite she/he will be and vice versa. $R$ gives flexibility to I to make choices so that I does not feel compelled to fulfill $\mathrm{R}$ demand.

Datum I/I/07

R : Assalamualaikum Ma'am. Maaf mengganggu. Ma'am kalau saya boleh tau materi Grammar Class kemarin apa ya, Ma'am?

*Author(s) Correspondence:

E-mail: widya.center@gmail.com 
$\mathrm{R}$ is asking $\mathrm{I}$ about the topic discussed in Grammar Class held last week. By using pronoun "Ma'am" four times, it seems that $\mathrm{R}$ really tries to be polite to I. Clause "Kalau saya boleh tau" indicates that $\mathrm{R}$ applies tac maxim by minimizing cost to other and maximizes benefit to other. By using costbenefit scale the politeness scale can be measured where $\mathrm{R}$ gives benefit of the proposed action to I. Option is also give to I that enables her to choose whether to answer R's question or not. She does not feel being imposed by R's question.

The violation of tact maxim is also identified in the data. It can be seen in the following conversation.

Datum 01/W/03

L : Ma'am mau tanya. Proposal untuk UTS, marginnya harus sudah sesuai sama yang di buku panduan ya?

$\mathrm{W}$ : (W does not reply)

A student (L) is contacting his lecturer (W) to ask about the thesis proposal that must be collected for mid semester exam. This datum is the opposite of the previous datum where the way student ask question to their lecturers is quite different. Violation against tact maxim here is indicated by the use of the phrase "mau tanya" that violates the two sub-maxims i.e. minimizing cost to other and maximizing benefits to other. By using the phrase "mau tanya", L does not provide any options for $\mathrm{W}$ to fulfill L's request. The data shows $\mathrm{W}$ does not answer questions from $\mathrm{L}$. In this case, according to the writer interpretation, $\mathrm{W}$ does not answer the question because the utterance does not meet the two sub-maxims of the tac maxim.

\section{Application and Violation of the Generosity Maxim}

In this maxim the participants of the speech are expected to respect each other. Respect for others will happen if people can minimize benefit to self and maximize cost to self. In other words, the utterance will meet this maxim if the speaker Examples of dialogues that meet generosity maxim are as follows.

Datum II/L/09

S : Selamat malam Ma'am L. Saya mau menanyakan soal latihan di kelas Prose analysis kita besok. Apakah kami harus membawa contoh prose masing-masing atau nanti proses nya dari Ma'am?

L : Malam. Oh iya, saya yang sediakan, tapi saya harus foto copy dulu nih.

S : Ma'am biar besok saya yang foto copy semua Ma'am. Besok saya bisa datang lebih awal.

$\mathrm{S}$ is a student of Prose Analysis class of L. She is offering help to copy material that will be discussed in class by saying "Ma'am biar besok saya yang foto copy semua Ma'am. Besok saya bisa datang lebih awal". The offer applies generosity maxim because $\mathrm{S}$ is trying to minimize benefit to self and to maximize cost to self. L gets benefit based on costbenefit scale and it is of course considered polite because the more the speech is detrimental to the speaker, the more polite it is.

The Violation of generosity maxim cannot be found in data because the data show that students prefer to be generous in acting when communicating with their lecturer. It might be caused by the authority of the lecture and the social distance between students and lecturers.

\section{Application and Violation of the Approbation Maxim}

By applying the approbation maxim speakers are required to minimize dispraise to other and maximize praise to other. At this maxim a compliment will be greatly appreciated, the speech utterances which are reproaches, ridicule or even insults will not be appreciated at all. In short, this maxim requires

\footnotetext{
*Author(s) Correspondence:

E-mail: widya.center@gmail.com
} 
that speakers praise others as much as possible and dispraise others as little as possible. The following conversation exemplifies the use of approbation maxim.

Datum III/I/10

$\mathrm{R}$ : Assalamualaikum ma'am I. Saya hanya mau mengingatkan kembali untuk Grammar Class yang nanti dibina/diajarkan oleh ma'am I, akan dilaksanakan pada jam $13.30 \mathrm{~s} / \mathrm{d}$ 15.10, di ruang kelas 406/4 ya Ma'am. Dan untuk materi yang nanti akan diberikan, itu ma'am saja yang menentukan karna Grammar Class ini dibuka untuk semua fakultas di UNAS ma'am. Sebelumnya terima kasih banyak ma'am karna sudah bersedia untuk menjadi pengajar di kelas Grammar.

I : Waalaikumsalam. Okay Rima. Saya ada kelas jam 9-1. Saya ingat kok.

Acknowledgments, which in Indonesian are often added with the word "banyak or banyakbanyak" to show deep gratitude, is one of the expressive illocutionary forces as the embodiment of approbation maxim with two sub maxims namele minimize dispraise to other and maximize praise to other. Acknowledgments show appreciation to other whose degree of civility can be measured by cost-benefit scale. The more profit given to others the higher the decency.

In addition to the above data examples, the authors found some other data that show the application of approbation maxim by using the phrase "terima kasih". Another example is as follows.

\section{Datum III/W/18}

E : Maaf ya ma'am merepotkan dan terima kasiiiih sekali selalu membantu saya.

I : Ya, sama-sama.

There is not any datum shows the violation of the approbation maxim. Authority and social

\footnotetext{
*Author(s) Correspondence:

E-mail: widya.center@gmail.com
}

distance scale are the cause of this phenomenon. The overall degree of respectfulness, for a given speech situation, depend largely on relatively permanent factor of status, age, degree of intimacy, etc., but also to some extent, on the temporary role of one person relatively to another. The different status between student and lecturer requires students to be able to choose appropriate utterance, particularly which is related to praise toward their lecturers.

\section{Application and Violation of the Modesty Maxim}

Modesty maxim requires speakers to minimize praise to self and to be modest. In other words, praise yourself as little as possible and dispraise self as much as possible. In this maxim the participants are not allowed to boast about themselves. Here is an example of an utterance with modesty maxim.

\section{Datum IV/I/16}

E : Besok jangan kaget kalo saya cengeng ya ma`am, saya orangnya super duper cengeng.

I : (replying by a smiley emoticon)

The context of this speech is a student who wants to share his problem and asks for his lecturer's advice to solve his academic problems. E says that she is a whiny and even a very crybaby, which is expressed with the phrase "super duper cengeng". In this context, E minimize to herself in order to increases the degree of courtesy of the utterance. Modesty in this speech can be measured with a costbenefit scale in which $E$ increases his selfesteem so that politeness increases. Instead, the following example shows the opposite situation with the fulfillment of modesty maxim, i.e. the violation of modesty maxim.

\section{Datum IV/L/16}

M : Assalamualaikum ma'am. Maaf mengganggu, ini saya M. KRS saya bisa belum disetujui dulu ga ma'am. Soalnya 
di akademik online saya communicative speaking skill 2 jadi Business and Professional English Ma'am.

L : Iya, itu betul.Comskill 2 itu conversion ke Business and Professional English, kan? Coba cek list conversi MK 2017 dulu.

\section{M : Berarti saya bener dong ma'am.}

From the above dialogue it can be seen that $M$ is breaking modesty maxim by breaking one of sub maxim that is minimize praise of self. The sentence "Berarti saya bener dong Ma,am" shows an excessive appreciation for oneself which decreases the level of decency of an utterance. Measured by indirectness scale, this utterance is considered is under politeness line because the student expresses his appreciation toward himself directly. This scale refers to the direct or indirect rating of the meaning of a speech. The more direct the utterance, the more impolite it will be and vice versa.

\section{Application and Violation of Agreement Maxim and Sympathy Maxim}

At agreement maxim the speaker is required to reduce the disagreement between himself and the speaker, but instead, increase the agreement between the two parties. Try to disagree with others as little as possible and try to deal with people as much as possible. In sympathy maxim the interlocutors are expected to to maximize the attitude of sympathy between one party with another party. The attitude of antipathy will be regarded as a disrespectful attitude. Briefly, reduce the antipathy between yourself, and increase the amount of sympathy between yourself and others. The following dialog shows the application of the agreement maxim and the sympathy maxim.

\section{Datum V/VI///13}

I : E maafkan saya. saya (maaf) muntahmuntah baru saja. Sepertinya saya tidak sanggup ke kampus besok.
E : Tidak apa-apa ma'am, bisa lain waktu. Nanti saya cancel juga yang sama bu W. Hehe. Semoga cepat sembuh ya Ma'am.

The above dialogue is about a lecturer (I) who canceled an appointment to meet his student (E) because of her illness. E denotes approval of I. E expresses it politely though E certainly feels disappointed because she can not meet I. The politeness scale of the utterance is measured by a cost-benefit scale in which $\mathrm{E}$ maximizes benefit for I while herself is harmed. The more the speech is detrimental to the speaker, the more polite it is and Vice versa. After giving an agreement to I, E adds her politeness level by using sympathy maxim by saying the sentence "Semoga cepat sembuh ya Ma'am" which shows his sympathy towards I.

There is not any data violating agreement maxim and sympathy maxims. The data show that students always succeeded in fulfilling agreement and sympathy maxim although based on the context of conversation, related to the pragmatics scale of politeness, they get cost to of the proposed action. Again, the different authority and social distance are responsible for this cost.

Some special cases are also found in this study. It is called case because the data do not show any violation toward the six politeness maxims but when they are measured by the pragmatics scales of politeness proposed by Leech. The following are some of them.

Datum X/D/01

$\mathrm{O}$ : Mam, kita hari ini ada KP ga?

D : Ngga dong. Makanya kuliah, jangan bolos mulu.

Datum X/D/04

$\mathrm{N}$ : Lho, Mam. Kita UTS juga?

D : Listening iya dong. Food and Cooking, Advertising, Hotel and Tourism, cm ttd.

\footnotetext{
*Author(s) Correspondence:

E-mail: widya.center@gmail.com
} 


\footnotetext{
Itu cum arsip SPA. Jadi instruksi presentasi-presntasi sebelumnya diuraikan.

$\mathrm{N}$ : ohhhh ok makasih Mam.

Datum X/D/07
A : Mamm D....!
Kita besok presentasi ngga mam?
D : Hadir
Presentasi Hotel and Tourism. Masih banyak yang belom gegara mati lampu.
A : Teyus gimana ma?
D : Apanya gimana?
A : Kita ga presentasi?
D : Lha? Gimana sih Lip? Ya besok kalo cukup waktunya, ya semuanya. Ga cukup ya pas UTS.

A : oh ya udah ok. Relax mam relax.
}

The above examples show us some dialogues between students and a lecturer. It seems that these dialogues might be considered less polite or even impolite because when they are measured by using indirectness scale they are all direct and it decreases the politeness rate of the utterance. From the authority scale these utterances are also considered less polite or impolite since in standard form lecturer has an authority so that the students are supposed to be more polite in communicating with the lecturer. Right and duties are supposed to be important in defining the standing of participants, particularly students and lecturer, in relation to one another. Thing that can be considered the cause of the flawlessness of the conversations is the social distance of the participants which refers to the scale of social relationship between speaker and hearer. There is a tendency where the closer the relationship is the less polite the utterance will be and vice versa. The lecturer feel that she is already has a close relationship with her students can consider such utterances as normal exchanges, not the impolite ones.

\section{CONCLUSION}

Leech uses the terms self and others in discussing about politeness principle and its maxims. Self refers to speakers and other refers to hearers and also to others, whether they are included in a speech situation or not. Politeness, according to Leech, is based on a) cost-benefit, b) dispraise and praise, c) agreement and disagreement, d) sympathy and antipathy. Then politeness is measured by using five pragmatic scales namely a) the costbenefit scale, b) the optionality scale, c) the indirectness scale, d) authority scale, and e) social distance scale. The results showed that the language used by students in communicating with the lecturer through WhatsApp is considered polite where the amount of politeness maxims application is much higher when compared to the violation of those maxims. Students' utterances show the application of tact maxim, generosity maxim, approbation maxim, modesty maxim, agreement maxim, sympathy and maxim sympathy embodied either in the form of words, phrases, or sentences. The context of speech is also very helpful for students to speak politely, i.e. most of the contexts indicate that the students contact the lecturers because there is a need or interest they should discuss with the lecturer related to their academic maters. The politeness of students' utterance in the data can be measured with the five pragmatics scales. Furthermore, violations are only found at tact and approbation maxim. The absence of violations of generosity, modesty, agreement, and sympathy maxim is due to the authority of the hearer and the social distance between speakers and hearers.

\footnotetext{
*Author(s) Correspondence:

E-mail: widya.center@gmail.com
} 


\section{REFERENCES}

Brown, P., \& Levinson, S. (1987). Politeness: some universals in language usage. Cambridge: Cambridge University Press.

Leech, G. (1983). Principle of pragmatics. London: Longman.
Gunarwan, A. (2007). Pragmatik: teori dan kajian nusantara. Jakarta: Penerbit Universitas Atma Jaya.

Nadar, FX. (2013). Pragmatik dan penelitian pragmatik. Yogyakarta: Graha Ilmu.

Wijana, I. D. P. (1996). Dasar-dasar pragmatik. Yogyakarta: Penerbit Abadi.

*Author(s) Correspondence:

E-mail: widya.center@gmail.com 